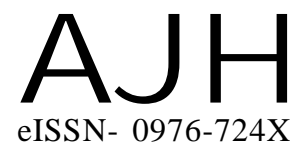

Received : 08.08.2016

Revised : 28.10 .2016

Accepted : 13.11 .2016
Members of the Research Forum

Associated Authors:

Department of Horticulture, Allahabad School of Agriculture, Sam Higginbottom Institute of Agriculture, Technology and Sciences, ALLAHABAD (U.P.) INDIA

Author for correspondence : KAMAL KANT

Department of Horticulture, Allahabad School of Agriculture, Sam Higginbottom Institute of Agriculture, Technology and Sciences, ALLAHABAD (U.P.) INDIA
THEASIAN JOURNALOF HORTICULTURE

Volume 11 | Issue 2 | December, 2016 | 338-343

Visit us -www.researchjournal.co.in

RESEARCH PAPER

DOI : 10.15740/HAS/TAJH/11.2/338-343

\section{Effect of microbial inoculants and chemical fertilizers on yield and economics of hybrid cabbage (Brassica oleracea var. capitata)}

\section{KAMAL KANT, DEVI SINGH ${ }^{1}$ AND V.M. PRASAD ${ }^{1}$}

ABSTRACT : The present investigation was carried out at Department of Horticulture, Allahabad School of Agriculture, SHIATS, Allahabad, U.P. during winter season of 2014-15 and 2015-16 in Factorial Randomized Block Design (RBD) for yield and quality contributing characters. The microbial inoculants (Azospirillum) significantly reduced the number of days taken to head initiation (52.20 days). The plants developed under NPK levels of $\mathrm{N}_{200} \mathrm{P}_{100} \mathrm{~K}_{100}$ along with microbial inoculant Azospirillum significantly produced the highest average head yield (1.753 $\mathrm{kg})$ per plant. The highest head yield $(787.47 \mathrm{q} / \mathrm{ha})$ was obtained with the use of microbial inoculant Azospirillum and proved its superiority over Azotobacter. For economics components the highest gross return (607954.67Rs./ha) was associated with NPK levels of $\mathrm{N}_{200} \mathrm{P}_{100} \mathrm{~K}_{100}+$ Azospirillum. Moreover, net return (463011.69Rs./ha) was associated with NPK level of $\mathrm{N}_{200}$ $\mathrm{P}_{100} \mathrm{~K}_{100}$ per hectare. The plants grown at NPK levels of $\mathrm{N}_{200} \mathrm{P}_{100} \mathrm{~K}_{100}$ per hectare produced significantly maximum benefit: cost ratio (3.96). Therefore, it may be concluded that application of microbial inoculants basically Azospirillum as soil application of NPK levels of $\mathrm{N}_{200} \mathrm{P}_{100} \mathrm{~K}_{100}$ per hectare was the most effective treatment combination for higher yield and economics in hybrid cabbage.

KEY WORDS : Azotobacter, Azospirillum, Cabbage, NPK, Yield, Economics

HOW TO CITE THIS ARTICLE : Kant, Kamal, Singh, Devi and Prasad, V.M. (2016). Effect of microbial inoculants and chemical fertilizers on yield and economics of hybrid cabbage (Brassica oleracea var. capitata). Asian J. Hort., 11(2) : 338-343, DOI : 10.15740/HAS/TAJH/11.2/338-343. 